\title{
The effect of dissolved oxygen on kinetics during continuous biocatalytic oxidations
}

\author{
Lindeque, Rowan M.; Woodley, John M.
}

Published in:

Organic Process Research And Development

Link to article, DOI:

10.1021/acs.oprd.0c00140

Publication date:

2020

Document Version

Peer reviewed version

Link back to DTU Orbit

Citation (APA):

Lindeque, R. M., \& Woodley, J. M. (2020). The effect of dissolved oxygen on kinetics during continuous biocatalytic oxidations. Organic Process Research And Development, 24(10), 2055-2063.

https://doi.org/10.1021/acs.oprd.0c00140

\section{General rights}

Copyright and moral rights for the publications made accessible in the public portal are retained by the authors and/or other copyright owners and it is a condition of accessing publications that users recognise and abide by the legal requirements associated with these rights.

- Users may download and print one copy of any publication from the public portal for the purpose of private study or research.

- You may not further distribute the material or use it for any profit-making activity or commercial gain

- You may freely distribute the URL identifying the publication in the public portal

If you believe that this document breaches copyright please contact us providing details, and we will remove access to the work immediately and investigate your claim. 


\title{
The effect of dissolved oxygen on kinetics during continuous biocatalytic oxidations
}

\author{
Rowan M. Lindeque and John M. Woodley* \\ Department of Chemical and Biochemical Engineering, Technical University of Denmark, Kgs. \\ Lyngby, 2800, Denmark
}



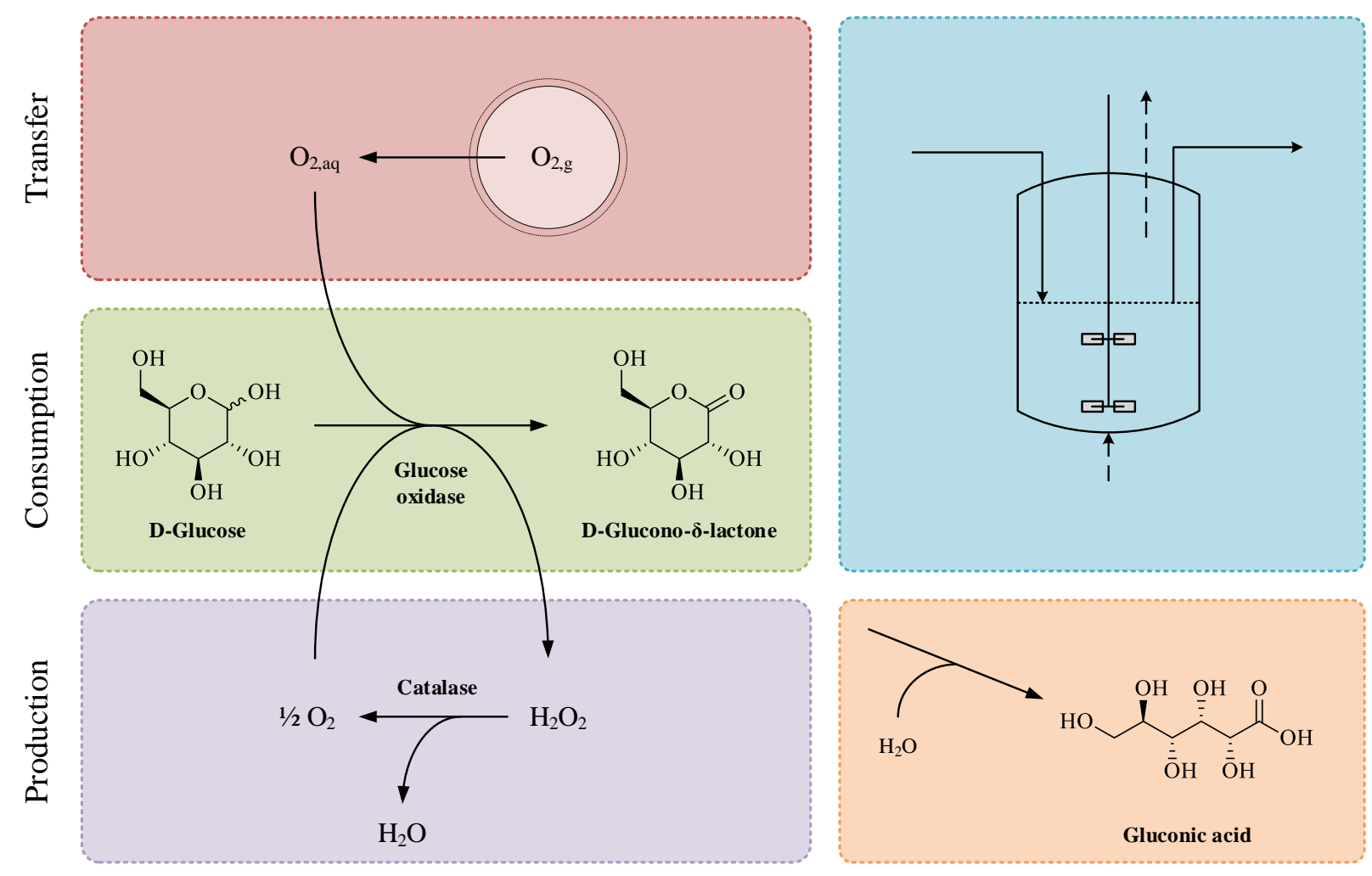


\section{ABSTRACT}

Conventional oxidation catalysts frequently exhibit limited selectivity, restricting their use in industrial syntheses. In particular, for the continuous synthesis of complex active pharmaceutical ingredients the high selectivity of biocatalytic oxidations is attractive. However, due to their dependence on gaseous molecular oxygen, which is poorly water soluble, such reactions are frequently limited by low dissolved oxygen concentrations. In order to better understand how oxygen-limitation influences the effectiveness with which an enzyme can be used, the continuous oxidation of glucose into gluconic acid, by glucose oxidase, was studied in a continuous stirred tank reactor. Results showed that a 3-fold increase in the oxygen content of the feed gas improved the reaction rate by twice as much as a 10 -fold increase in enzyme concentration, confirming that the reaction is most sensitive to dissolved oxygen concentrations. Therefore, the enzyme could, on average, be used four times more effectively at an enzyme concentration of $0.1 \mathrm{~g} . \mathrm{L}^{-1}$ than at $1 \mathrm{~g} . \mathrm{L}^{-}$ ${ }^{1}$, due to higher dissolved oxygen concentrations at steady state. However, at feed gas compositions greater than $60 \%$ oxygen, reaction rates began to drop due to enzyme deactivation. It was also found that the measurement of mass transfer coefficients is significantly affected by media composition, which may lead to inaccurate predictions of reaction rate.

KEYWORDS: dissolved oxygen, continuous, biocatalysis, oxidation, CSTR 


\section{INTRODUCTION}

In order to facilitate the production of an ever-wider variety of novel and complex organic molecules, for use as active pharmaceuticals ingredients (APIs), the highest selectivity possible is required across the full spectrum of reaction chemistries. For instance, while oxidation reactions, which are important for synthesizing alcohols, ketones, aldehydes and acids, are widely used in industry for the production of simple commodity chemicals, they are comparatively rarely applied in pharmaceutical syntheses, because conventional catalysts are poorly selective towards complex molecules and require harsh operating conditions. ${ }^{1-5}$ Consequently, biocatalytic oxidations, which are far more selective and require significantly milder operating conditions (room temperature and pressure, as well as neutral $\mathrm{pH}$ ), are becoming increasingly attractive for industrial implementation. ${ }^{6-8}$ However, since the pharmaceutical industry and its regulators are shifting in favor of continuous end-to-end manufacturing, to improve the agility and flexibility with which drugs can be supplied ${ }^{9-13}$, biocatalysis must also follow suit.

Such continuous processes operate best in tubes (in plug flow mode) affording excellent kinetics and the possibility of complete conversion, with much reduced 'downtime' and a precise residence time (without a distribution). ${ }^{14}$ However, this presents a particular challenge for the implementation of those biocatalytic reactions which contain more than just a single liquid reaction phase $^{15}$, such as oxidations that use molecular oxygen as a substrate. Therefore, either alternate reactor configurations are required, or a means of reducing the reaction to a single phase. There are three subclasses of enzymes that use molecular oxygen to catalyze oxidation reactions; oxidases, monooxygenases and dioxygenases. Of these, the oxidases are of particular interest since, unlike most oxidoreductases ${ }^{16-18}$, they are not dependent on expensive nicotinamide cofactors. While there are several advantages to using molecular oxygen, namely that it is benign, 
abundant and inexpensive when supplied in the form of air, its poor solubility in water $(0.26 \mathrm{mM}$ in equilibrium with air at $25^{\circ} \mathrm{C}$ and $1 \mathrm{~atm}$, based on Henry's Law constant ${ }^{19}$ ) generally prevents it from being supplied at adequate concentrations in its dissolved state. ${ }^{20}$

There are three alternatives for supplying molecular oxygen to a continuous biocatalytic oxidation. The first is to feed the reaction with a liquid stream containing dissolved oxygen (DO). The solubility of oxygen increases proportionally with pressure. Therefore, a higher DO concentration can be fed to a process by operating at elevated pressures. Using this principle, a six-fold improvement in the reaction rate of glucose oxidase was achieved by operating a tubular microreactor at 34 bar, which raised the oxygen solubility to $43 \mathrm{mM} \cdot{ }^{21}$ While this does allow higher reaction rates at the start of a tubular reactor, the maximum product titer that can be achieved at the reactor outlet is still limited due to the stoichiometry of oxidase-catalyzed reactions ( $1 \mathrm{~mol}$ substrate and $1 \mathrm{~mol} \mathrm{O}_{2}$ gives 1 mol product). Moreover, this technique greatly increases the capital and operating costs of an industrial scale process, as well as introduces a significant safety risk. The second possibility is to generate the DO required for the oxidation reaction in situ. One way of doing this is through the use of the enzyme catalase $\mathrm{e}^{22}$, which can convert hydrogen peroxide into oxygen and water. This approach was recently used to increase the productivity of galactose oxidase 5-fold in a tubular microreactor. ${ }^{23}$ However, this requires a continuous supply of hydrogen peroxide in excess to the reaction, due to the unfavorable stoichiometry of catalase ( $1 \mathrm{~mol} \mathrm{H}_{2} \mathrm{O}_{2}$ gives $0.5 \mathrm{~mol} \mathrm{O}_{2}$ ). Hydrogen peroxide can, in some cases, modify the peptide core of an enzyme as well as oxidize some cofactors and prosthetic groups, which may negatively impact enzyme activity or stability. ${ }^{24,25}$ For instance, variants of glucose oxidase ${ }^{26-28}$, laccase ${ }^{29}$, bilirubin oxidase $^{30}$, D-amino acid oxidase ${ }^{31-34}$ and glycolate oxidase ${ }^{35}$, as well as catalase itself ${ }^{36}$, to name a few $^{37-41}$, have all been found to be inhibited and/or inactivated by hydrogen peroxide, at 
concentrations as low as $1.5 \mathrm{mM}$ in some cases. Of course, this does not guarantee that all oxygendependent enzymes, or variants thereof, are equally affected by hydrogen peroxide. Therefore, the suitability of this method for bypassing gas-liquid mass transfer should be assessed on a case-bycase basis. Another consideration is that the high reactivity and exothermic decomposition of hydrogen peroxide can raise the explosion risk of a chemical process ${ }^{42}$, especially when used in combination with certain solvents, acids or bases ${ }^{43-47}$. This incurs additional costs to ensure safe handling at a larger scale. While this may not be a problem for most biocatalytic processes, which operate under very mild conditions (aqueous, low temperature, low pressure) ${ }^{48}$, the growing use of protein engineering or immobilization to improve enzyme tolerance towards elevated temperatures ${ }^{49-51}$ and/or volatile organic solvents ${ }^{52-54}$ could make reactions using more exotic conditions less stable in the presence of hydrogen peroxide. The third possibility is to continuously supply the liquid reaction phase with a gas containing oxygen (most usually air), which can then transfer into the liquid phase, driven by mass action. Here, the solubility of oxygen can be increased by raising the partial pressure of oxygen in the feed gas. Due to its simplicity, this approach is attractive for rapid implementation of biocatalytic oxidations at industrial scale.

Therefore, the aim of this work was to broaden our understanding of oxygen dependence during continuous biocatalytic oxidations in a well-mixed reactor involving gas-liquid mass transfer and its influence on the effectiveness with which oxidases can be used. The well-described oxidation of glucose to gluconic acid by glucose oxidase (GOx), coupled with catalase, was selected as a model system for laboratory scale experiments. 


\section{GAS-LIQUID MASS TRANSFER}

Gaseous molecular oxygen can be supplied to a continuous reaction in many ways e.g. through a gas permeable membrane in a tube-in-tube configuration ${ }^{55}$, by segmented flow of alternately gas and liquid in a single tube ${ }^{56}$ or simply by bubbling the gas into a stirred tank. Regardless of how the gas is supplied, the important factor to consider is the interfacial area between the gas and liquid phases over which gas-liquid mass transfer occurs. This is represented by the specific surface area of the reactor, in this case the area of gas-liquid interface per liquid volume. The larger the specific surface area, the faster oxygen can be supplied to the oxidation reaction occurring in the bulk of the liquid phase, enabling higher reaction rates. Unfortunately, while tubular reactor configurations are generally attractive for continuous operation, their specific surface areas are determined by the tube dimensions. Specifically, in a tube-in-tube configuration, the area of the gas-liquid interface is equivalent to the inner surface area of the tube in contact with the reaction media while, in a segmented flow configuration, the tube diameter dictates the size of the gas bubbles in contact with the reaction media. Therefore, at small tube diameters, the surface-tovolume ratios are high, resulting in large specific surface areas that enable rapid gas-liquid mass transfer. Yet, small diameter tubes are subject to large pressure drops and, furthermore, can easily become clogged, which limits their use in industrial applications. On the other hand, increasing the diameter of a tubular reactor dramatically decreases its specific surface area, as shown in Figure 1. In contrast, interfacial areas in stirred tanks (bubbled with air or any gas containing oxygen) of equivalent volume typically increase with scale ${ }^{57}$. This is very attractive for streamlining industrial implementation of continuous biocatalytic oxidations, since the design, scale-up, operation and control of stirred tank reactors is well researched. ${ }^{58-61}$ Furthermore, batch stirred tank reactors are already widely applied in many industrial pharmaceutical production processes ${ }^{1}$ and can easily be 
retrofitted to operate continuously, especially since aerated batch reactors already operate continuously with respect to the gas phase. For this reason, laboratory experiments were carried out in a continuous stirred tank reactor (CSTR).

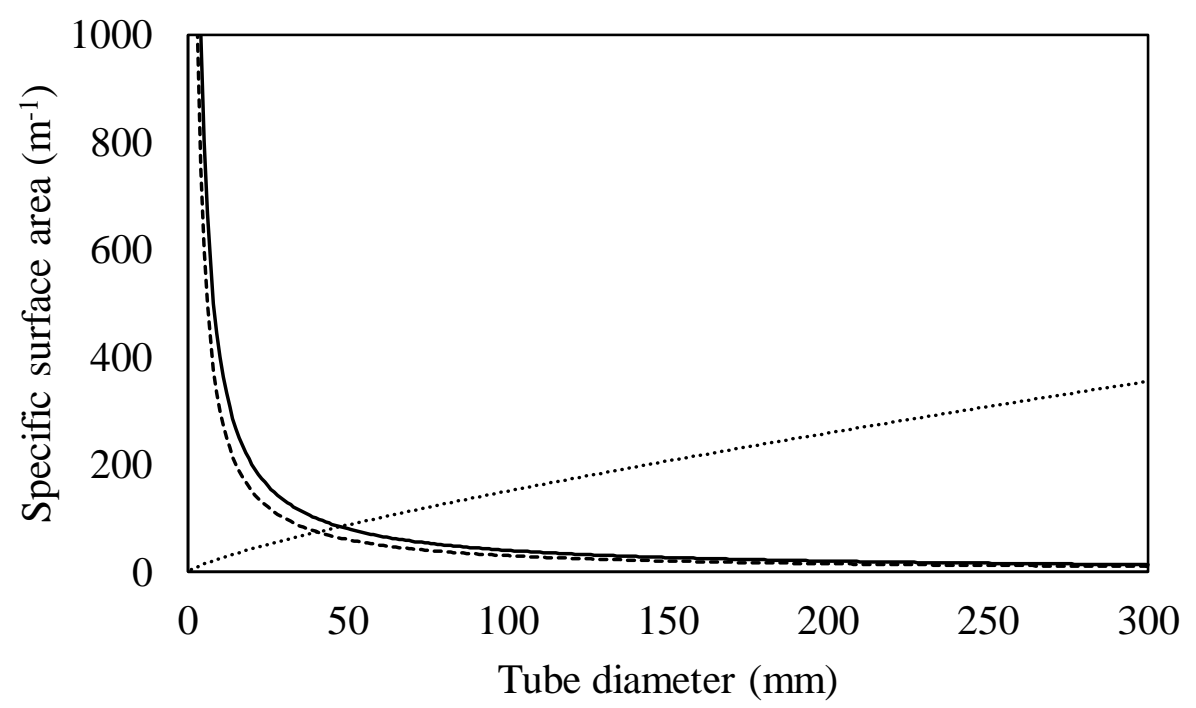

Figure 1. Gas-liquid interfacial areas of tube-in-tube reactor (solid line) and segmented flow reactor $(\mathrm{SFR})$ (dashed line) at different diameters (length $=1 \mathrm{~m}$ ), as well as a continuous stirred tank reactor (CSTR) of equivalent volume (dotted line). For the SFR, equidistant spherical bubbles with diameters equal to that of the tube were assumed. For the CSTR, specific surface area was estimated using correlations for volumetric mass transfer coefficient $\left(\mathrm{k}_{\mathrm{L}} \mathrm{a}\right)^{62}$ and liquid side mass transfer coefficient $\left(\mathrm{k}_{\mathrm{L}}\right)^{63}$. Detailed calculations can be found in Chapters 6 and 11 of the Handbook of Industrial Mixing. ${ }^{64}$ 


\section{MATERIALS AND METHODS}

Glucose oxidase (GOx) used in the experiments $\left(\right.$ Novozym $\left.^{\circledR} 28166\right)$ was kindly donated by Novozymes A/S, Denmark. All other chemicals and catalase were purchased from Sigma-Aldrich, Denmark. Reactions were carried out in a $150 \mathrm{~mL}$ (liquid volume) my-Control stirred tank reactor (Applikon Biotechnology B.V., Netherlands), as illustrated in Figure 2. An Ismatec Reglo Independent Channel Control peristaltic pump (Cole-Parmer, USA) was used to supply the reactor with an enzyme feed (0.2-2 g.L $\mathrm{L}^{-1} \mathrm{GOx}, 0.2-2 \mathrm{~g} . \mathrm{L}^{-1}$ bovine liver catalase, $100 \mathrm{mM} \mathrm{pH} 7$ potassium phosphate buffer) and a substrate feed (2 M glucose, $100 \mathrm{mM} \mathrm{pH} 7$ potassium phosphate buffer), each at a rate of $1.5 \mathrm{~mL} \cdot \mathrm{min}^{-1}$, as well as pump the mixed reactor contents out of the vessel at a rate of $3 \mathrm{~mL} \cdot \mathrm{min}^{-1}$. Therefore, overall feed concentrations into the reactor were $1 \mathrm{M}$ glucose and 0.1-1 g.L $\mathrm{L}^{-1}$ GOx and catalase with a dilution rate of $1.2 \mathrm{~h}^{-1}$. These same concentrations were used to initiate each reaction. Catalase was supplied to the reaction as a means of removing hydrogen peroxide, a by-product of the oxidation reaction, to avoid inhibition and/or deactivation of the GOx. Catalase is a highly active enzyme and so the use of reactor catalase concentrations equal to that of GOx ensured that hydrogen peroxide was consumed virtually as quickly as it was produced. The reactor was sparged at $1 \mathrm{vvm}$ (volume gas per volume reaction liquid per minute) with gas (composed of varying ratios of nitrogen and oxygen) and was agitated at $1000 \mathrm{rpm}$ to ensure wellmixed conditions. When subjected to these conditions, with air as the feed gas, the GOx activity was measured to be constant for at least $100 \mathrm{~min}$, twice as long as the mean residence time in the reactor (data not shown). Off-gas from the reactor was passed through a condenser to avoid volume-loss due to stripping. The temperature and $\mathrm{pH}$ of the reactor contents were controlled at $25^{\circ} \mathrm{C}$ and $\mathrm{pH} 7$, to match the conditions at which kinetic parameters for GOx were available. The reactor was operated as a $\mathrm{pH}$-stat, whereby a PI controller regulated the addition of $5 \mathrm{M} \mathrm{NaOH}$ to 
the media to maintain the desired $\mathrm{pH}$, based on measurements from a $\mathrm{pH}$ probe in the reactor. Foam formation in the reactor was controlled by manual dropwise addition of Antifoam 204.

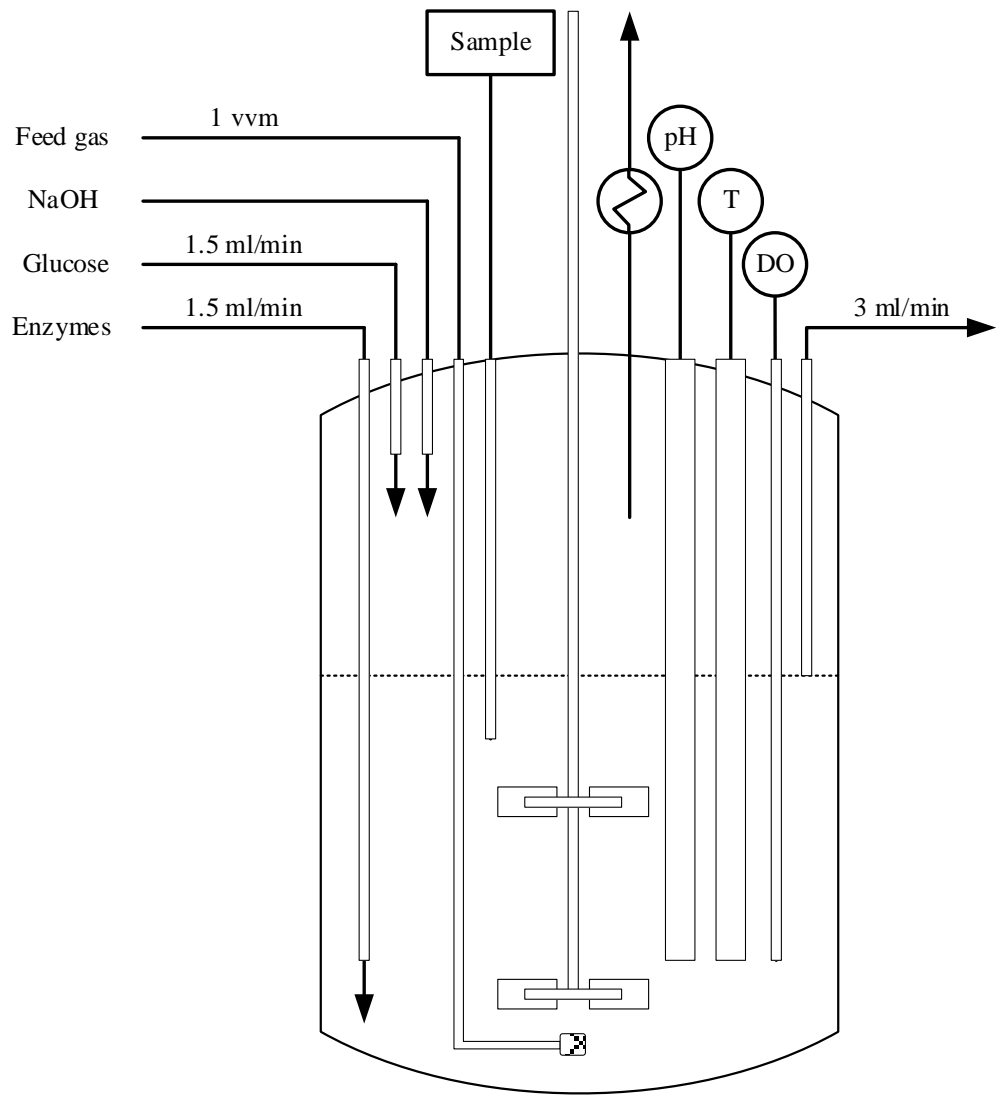

Figure 2. CSTR setup for continuous biocatalytic oxidation of glucose to gluconic acid. Two flights of Rushton impellers were used for mixing. Due to the small liquid volume (150 mL) and number of internals, no additional baffles were included.

$\mathrm{O}_{2}$ saturation (\%) in the reactor was monitored and logged using a robust optical oxygen probe (Pyroscience AT GmbH, Germany). The probe was calibrated by saturating the reaction media, prior to initiation of the reaction by addition of the enzymes, with nitrogen to achieve $0 \% \mathrm{O}_{2}$ saturation and separately, pure oxygen to achieve $100 \% \mathrm{O}_{2}$ saturation. Percentage $\mathrm{O}_{2}$ saturation was converted to dissolved oxygen concentration (mM) using the Henry's Law constant of oxygen in water $\left(1.2 \times 10^{-5} \mathrm{~mol} \cdot \mathrm{m}^{-3} \cdot \mathrm{Pa}^{-1}\right) \cdot{ }^{19}$ During operation, samples $(950 \mu \mathrm{L})$ were taken from the reactor 
at regular intervals, using $50 \mu \mathrm{L}$ of $5 \mathrm{M} \mathrm{H}_{2} \mathrm{SO}_{4}$ to quench the reactions. These samples were then analyzed by HPLC in an Aminex HPX-87H column (Bio-Rad Laboratories, Inc., USA), at $20^{\circ} \mathrm{C}$ with a mobile phase flow rate of $0.6 \mathrm{~mL} \cdot \mathrm{min}^{-1}$ of $5 \mathrm{mM} \mathrm{H}_{2} \mathrm{SO}_{4}$. Refractive Index (RI) and $205 \mathrm{~nm}$ Ultraviolet (UV) spectra were used to determine the glucose and gluconic acid concentrations, respectively. Each reaction was monitored for 6 hours ( $>7$ residence times), to guarantee that steady-state operation could be achieved across all operating conditions.

\section{RESULTS AND DISCUSSION}

The reaction catalyzed by GOx, shown in Scheme 1, exhibits a ping-pong bi-bi rate law (Equation 1), in which the oxygen consumption rate (OCR) is dependent on the concentrations of GOx $\left(\mathrm{C}_{\mathrm{GOx}}\right)$, glucose $\left(\mathrm{C}_{\mathrm{G}}\right)$ and dissolved oxygen $\left(\mathrm{C}_{\mathrm{O}}\right)$. The rate constant of the enzyme $\left(\mathrm{k}_{\mathrm{cat}}\right)$ and its affinity constants towards glucose $\left(\mathrm{K}_{\mathrm{MG}}\right)$ and oxygen $\left(\mathrm{K}_{\mathrm{MO}}\right)$ were previously measured in our laboratory in a specially adapted tube-in-tube reactor. The small diameter of the tube-in-tube

reactor used in this study $(0.23 \mathrm{~mm})$ gave an extremely large specific surface area $\left(17391 \mathrm{~m}^{-1}\right)$ and very short diffusion distances. Additionally, it could be operated at pressures up to 10 bar. These features allowed DO concentrations of up to $12 \mathrm{mM}$ to be reached, making the reactor ideal for measuring the kinetic parameters of enzymes that are dependent on hydrophobic, poorly watersoluble gases (such as oxygen). 
Scheme 1. GOx-catalyzed conversion of D-glucose to D-glucono- $\delta$-lactone, which spontaneously hydrolyzes to form gluconic acid.<smiles>OC[C@H]1O[C@H](O)[C@@H](O)[C@H](O)[C@H]1O</smiles><smiles>CC(CO)C[C@H](C)CO[C@H](O)[C@@H](O)[C@H](O)[C@H](O)C(=O)O</smiles>

$$
\text { OCR }=\frac{\mathrm{k}_{\mathrm{cat}} \mathrm{C}_{\mathrm{GOx}} \mathrm{C}_{\mathrm{G}} \mathrm{C}_{\mathrm{O}}}{\mathrm{K}_{\mathrm{MG}} \mathrm{C}_{\mathrm{O}}+\mathrm{K}_{\mathrm{MO}} \mathrm{C}_{\mathrm{G}}+\mathrm{C}_{\mathrm{G}} \mathrm{C}_{\mathrm{O}}}
$$

Table 1. Kinetic parameters of $\mathrm{GOx}^{65}$

\begin{tabular}{lll}
\hline Kinetic parameter & Value & Unit \\
\hline $\mathrm{k}_{\mathrm{cat}}$ & $17.8 \pm 1.39$ & $\mu \mathrm{mol} \cdot \mathrm{min}^{-1} \cdot \mathrm{mg}_{\mathrm{GOx}}{ }^{-1}$ \\
$\mathrm{~K}_{\mathrm{MG}}$ & $75.2 \pm 9.38$ & $\mathrm{mM}$ \\
$\mathrm{K}_{\mathrm{MO}}$ & $0.51 \pm 0.09$ & $\mathrm{mM}$ \\
\hline
\end{tabular}

An initial baseline experiment was carried out in a continuous stirred tank reactor (CSTR) with air as the feed gas and 0.1 g. $\mathrm{L}^{-1} \mathrm{GOx}$ and catalase in the reactor. The resulting concentration profiles of glucose, gluconic acid and dissolved oxygen, over the course of the experiment, are shown in Figure 3. High initial and feed concentrations $(\sim 1 \mathrm{M})$ of glucose, relative to the $\mathrm{K}_{\mathrm{MG}}$ of GOx, were used to ensure that oxygen availability would be the dominant rate-limiting factor during the experiment, resulting in a glucose conversion of only $12 \%$.

The solubility of oxygen in water is generally very low. For instance, when supplied as air (21\% $\left.\mathrm{O}_{2}\right)$ its solubility is only $0.26 \mathrm{mM}$ at ambient conditions $\left(25^{\circ} \mathrm{C}, 1 \mathrm{~atm}\right) .{ }^{66}$ This greatly limits the 
driving force for gas-liquid mass transfer of oxygen, regardless of the specific gas-liquid surface area. ${ }^{20,67}$ Additionally, the affinity constants of many oxidases towards oxygen $\left(\mathrm{K}_{\mathrm{MO}}\right)$ are generally high relative to oxygen aqueous solubility at atmospheric pressure, based on data available in the BRENDA database ${ }^{68}$ For instance, the steady-state DO concentration measured in the baseline experiment $(0.18 \mathrm{mM})$ is almost 3-fold lower than the measured $\mathrm{K}_{\mathrm{MO}}$ of GOx. Therefore, the GOx can only operate at $26 \%$ of its maximum rate $\left(\mathrm{Vmax}=\mathrm{k}_{\mathrm{cat}} \mathrm{C}_{\mathrm{GOx}}\right)$, according to Equation 1 .

We reasoned that, because our system is primarily oxygen limited, the rate could be improved by increasing the aqueous solubility of oxygen, allowing higher dissolved concentrations at steady state. This can be accomplished by increasing the oxygen partial pressure, either through mildly pressurizing the system or by supplying oxygen-enriched air $\left(>21 \% \mathrm{O}_{2}\right)$. However, Equation 1 also indicates that the OCR, which is stoichiometrically equivalent to the overall rate of reaction, is directly proportional to the enzyme concentration and so the most apparent means of improving productivity would be to simply increase the concentration of GOx in the reactor. Nevertheless, as illustrated by Figure 4, we surmised that this may not yield the expected return at low DO concentrations. In order to test this, additional experiments were carried out with higher concentrations of GOx and catalase (1 g.. $\left.\mathrm{L}^{-1}\right)$ as well as with feed gas mixtures containing more oxygen (60, 80 and 100\%). The average gluconic acid concentration over the final hour of each experiment was multiplied with the dilution rate $\left(1.2 \mathrm{~h}^{-1}\right)$ to obtain the OCRs shown in Figure 5. 

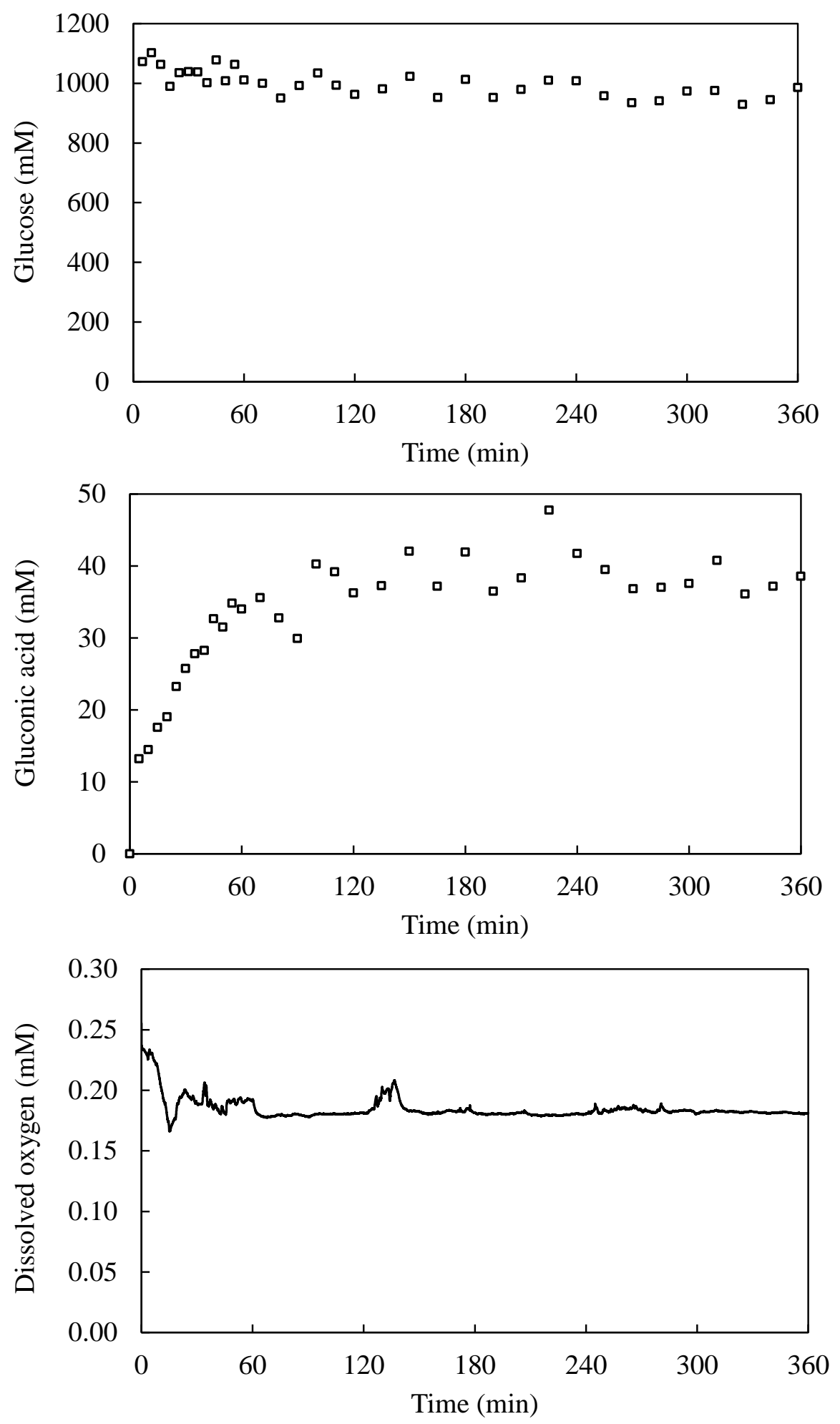

Figure 3. Glucose, gluconic acid and dissolved oxygen concentration profiles of baseline experiment with 0.1 g.L. $\mathrm{L}^{-1}$ glucose oxidase and catalase, using air $\left(21 \% \mathrm{O}_{2}\right)$ as feed gas. 


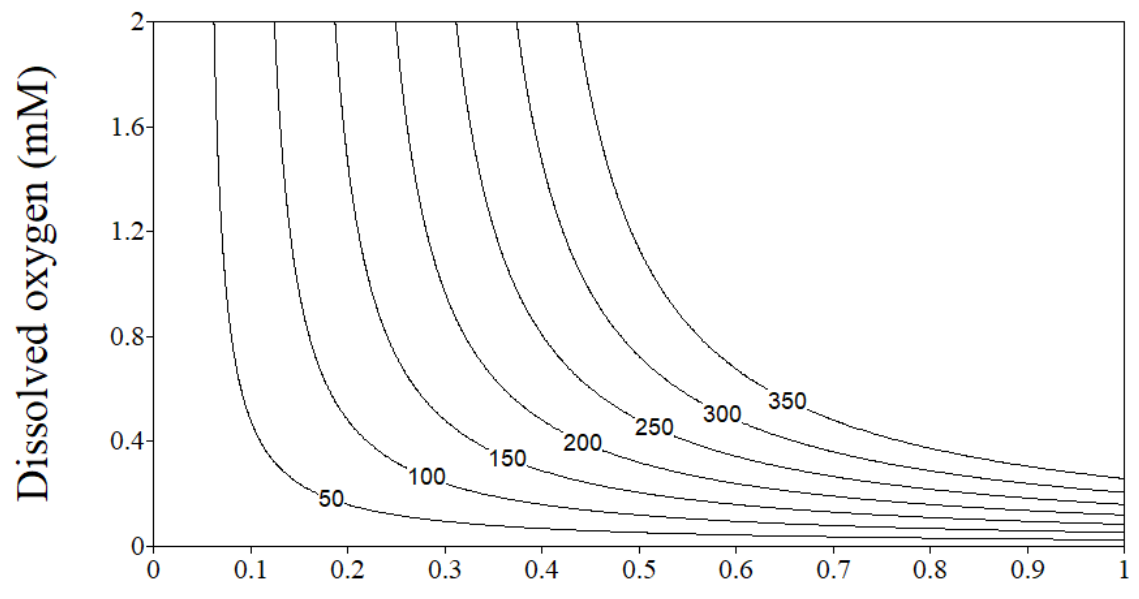

Enzyme concentration $(\mathrm{g} / \mathrm{L})$

Figure 4. Dependence of glucose oxidase reaction rate on concentrations of dissolved oxygen and GOx, based on ping-pong bi-bi rate law. Each contour represents a constant OCR $\left(\mathrm{mmol} \cdot \mathrm{L}^{-1} \cdot \mathrm{h}^{-1}\right)$.

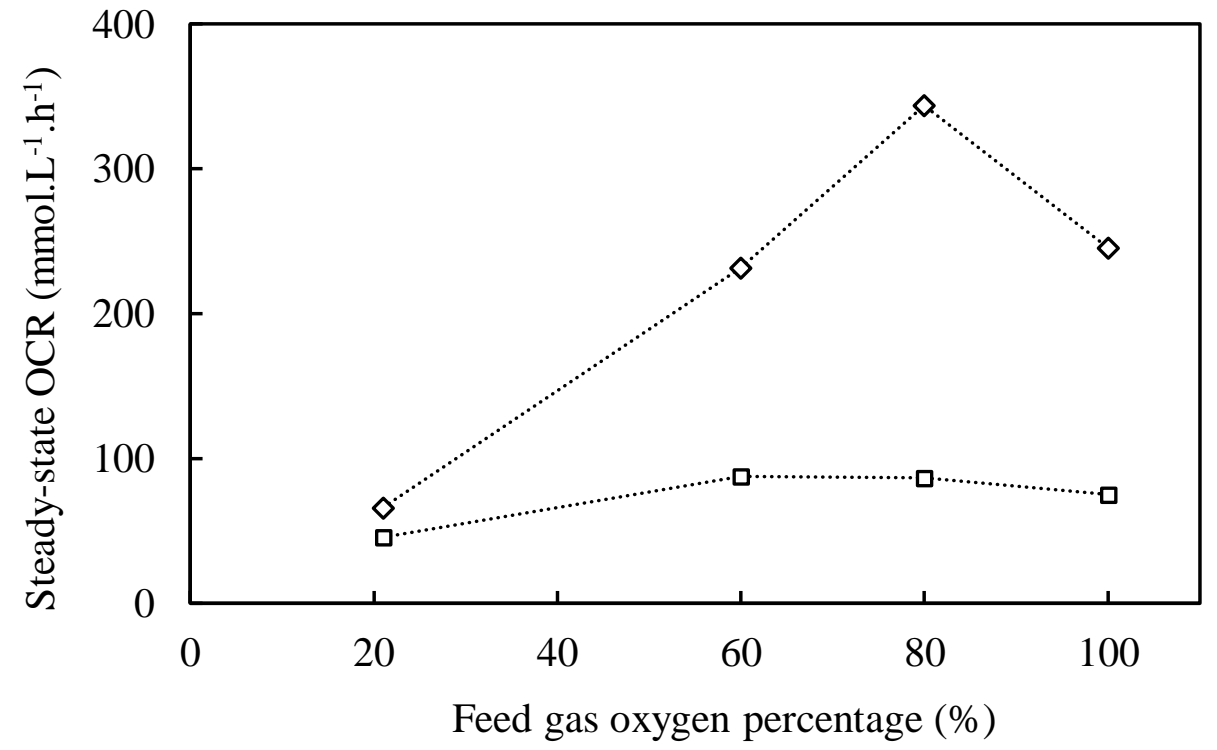

Figure 5. Steady-state OCRs of experiments with various feed gas oxygen contents and GOx concentrations of 0.1 g.L $\mathrm{L}^{-1}(\square)$ and 1 g.L $\mathrm{L}^{-1}(\diamond)$. 
When supplied with oxygen-rich feed gas, the OCRs during experiments with 1 g.L $\mathrm{L}^{-1}$ GOx were significantly higher than any experiment at the reduced enzyme concentration. However, this was not the case when air was used as the feed gas. Compared to the baseline experiment, increasing the GOx concentration by 10 -fold only gave a 1.4-fold increase in OCR. In contrast, a 3 -fold increase in the oxygen content of the feed gas nearly doubled the OCR, despite the presence of less GOx. This confirms that the system is more sensitive to changes in DO concentration because it is the dominant rate-limiting factor. Increasing the enzyme concentration alone resulted in a significant drop in the steady-state DO concentration within the reactor, to approximately $0.02 \mathrm{mM}$ (23-fold lower than the $\mathrm{K}_{\mathrm{MO}}$ ). Meanwhile, switching the feed gas from air to $60 \%$ oxygen allowed the DO concentration in the reactor to stabilize at $0.61 \mathrm{mM}$ (1.2-fold higher than the $\left.\mathrm{K}_{\mathrm{MO}}\right)$. Therefore, while it is theoretically possible to improve reaction rates arbitrarily by simply adding more catalyst, it generally reduces the effectiveness with which the catalyst can be used. This tradeoff can be seen through a comparison of the specific steady-state OCRs $\left(\mathrm{mmol}_{\mathrm{g}} \mathrm{gOx}^{-1} \cdot \mathrm{h}^{-1}\right)$ of each experiment, as shown in Figure 6. In general, the lower enzyme concentrations allowed higher steady-state DO concentrations, thus making more effective use of the GOx since it was able to operate closer to its maximum rate. This reduces the amount of enzyme required to achieve a desired productivity, which is highly desirable at industrial scale. Therefore, increasing the DO concentration is both a more efficient and economical means of improving reaction performance, as it makes better use of a costly catalyst. Even so, the enzyme is still being used somewhat ineffectively since the degree to which it is saturated with oxygen is less than that of its saturation with glucose $\left(\mathrm{C}_{\mathrm{O}} / \mathrm{K}_{\mathrm{MO}}<<\mathrm{C}_{\mathrm{G}} / \mathrm{K}_{\mathrm{MG}}\right)$. Additionally, the use of oxygen-enriched air in an industrial process presents a safety risk that would necessitate additional costs for safe handling procedures. 


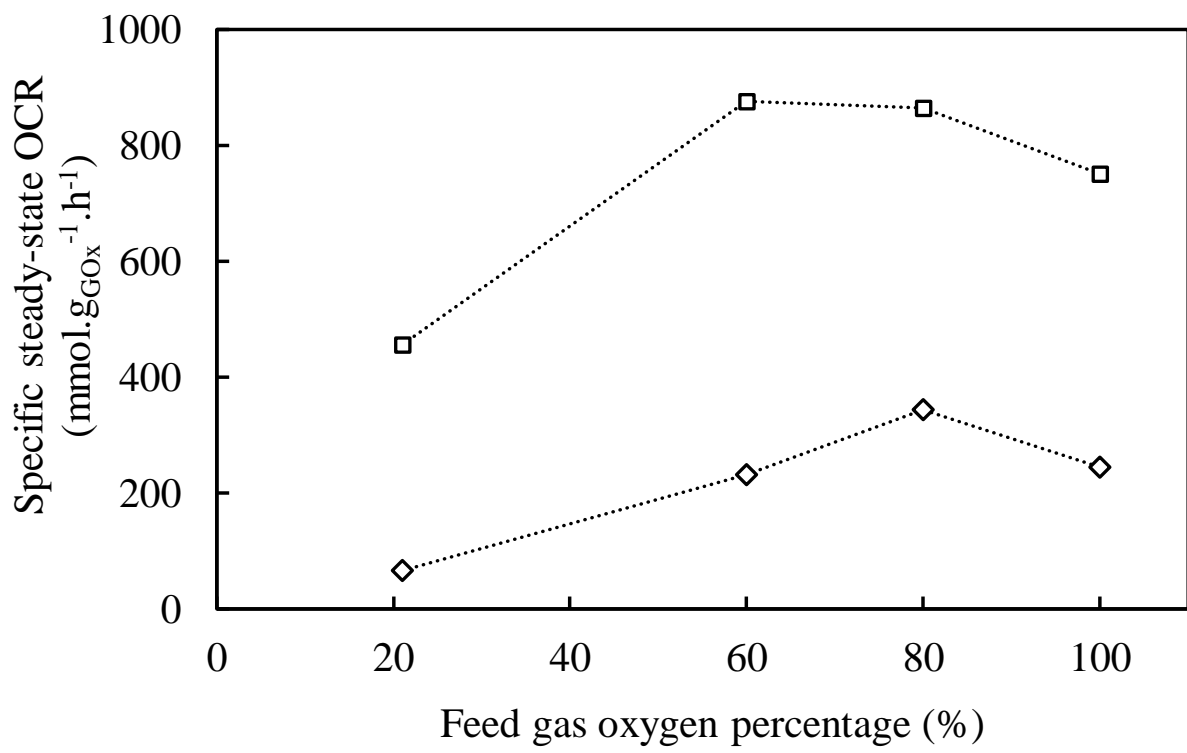

Figure 6. Specific steady-state OCRs of experiments with various feed gas oxygen contents and GOx concentrations of 0.1 g.L $\mathrm{L}^{-1}(\square)$ and 1 g.L $\mathrm{L}^{-1}(\diamond)$.

At feed gas oxygen contents above $60 \%$, the OCR begins to drop at the lower enzyme concentration. A similar drop occurs at the higher enzyme concentration above a feed gas oxygen content of $80 \%$. The same trend has previously been observed in experiments with cyclohexanone monooxygenase ${ }^{69}$ Since the effect was detected sooner at lower enzyme concentrations, it points towards enzyme deactivation. However, as there is a large difference in the steady-state DO concentrations of the experiments using pure oxygen as feed gas $\left(1.11 \mathrm{mM}\right.$ at $0.1 \mathrm{~g} . \mathrm{L}^{-1} \mathrm{GOx}$ and $0.10 \mathrm{mM}$ at 1 g.L $\left.\mathrm{L}^{-1} \mathrm{GOx}\right)$, the deactivation does not appear to result from oxygen in the liquid phase, although this may simply be due to the fact that the dissolved concentrations are too low to cause deactivation. Therefore, it would seem that GOx is deactivated by contact with the interface of an oxygen-rich gas. A number of enzymes have been found to be deactivated by direct exposure to hydrophobic gas-liquid interfaces. ${ }^{70-74}$ Additionally, the presence of oxygen in the gas phase may oxidize amino acids on the enzyme surface, as is the case with hydrogenase ${ }^{75,76}$ and D-amino acid oxidase ${ }^{33}$. This limits the degree to which increased oxygen partial pressure can be effectively 
used to improve performance. The addition of surfactants to the reaction mixture may reduce this effect by preferentially binding with the gas-liquid interface to avoid direct contact with the enzyme. $^{70,71,75,77}$ Likewise, various methods of immobilization have been described to avoid enzyme deactivation at gas-liquid interfaces. ${ }^{74,78}$

The mass transfer coefficient $\left(\mathrm{k}_{\mathrm{L}} \mathrm{a}\right)$ of the reactor was determined to be $80 \mathrm{~h}^{-1}$ in distilled water at ambient conditions, according to the standard gassing-in method ${ }^{79}$. Using the average DO concentration over the final hour of each experiment, the corresponding steady-state oxygen transfer rate (OTR) in the reactor was calculated, according to Equation 2, where $\mathrm{Co}_{\mathrm{O}}{ }^{*}$ is the partial pressure-dependent solubility of oxygen in water (i.e. at equilibrium: $0.26 \mathrm{mM}$ for air or $1.22 \mathrm{mM}$ for pure oxygen at $1 \mathrm{~atm}, 25^{\circ} \mathrm{C}$ ). These results are shown in Table 2 .

$$
\text { OTR }=\mathrm{k}_{\mathrm{L}} \mathrm{a}\left(\mathrm{C}_{\mathrm{O}}^{*}-\mathrm{C}_{\mathrm{O}}\right)
$$

In the absence of catalase, steady state would be achieved when the rate at which oxygen is consumed is equal to the rate at which it is transferred from the gas to the liquid phase (OCR $=$ OTR) ${ }^{80}$ However, since catalase produces dissolved oxygen, with a theoretical maximum rate equal to half that of the OCR, gas-liquid oxygen transfer only accounts for a portion of the oxygen consumed, the rest of which must be produced by catalase (Equation 3). Table 2 also shows the estimated oxygen production rates (OPRs) of each experiment, as well as their contribution towards the OCR (i.e. OPR/OCR).

$$
\mathrm{OPR}=\mathrm{OCR}-\mathrm{OTR}
$$


Table 2. Measured dissolved oxygen concentrations at steady state used to estimate oxygen transfer rate of each experiment for comparison with corresponding oxygen consumption rate.

\begin{tabular}{ccccccc}
\hline $\begin{array}{c}\text { GOx } \\
(\mathrm{g} / \mathrm{L})\end{array}$ & $\begin{array}{c}\text { Feed gas } \\
\left(\% \mathrm{O}_{2}\right)\end{array}$ & $\begin{array}{c}\text { DO } \\
(\mathrm{mM})\end{array}$ & $\begin{array}{c}\text { OTR } \\
(\mathrm{mmol} / \mathrm{L} . \mathrm{h})\end{array}$ & $\begin{array}{c}\text { OCR } \\
(\mathrm{mmol} / \mathrm{L} . \mathrm{h})\end{array}$ & $\begin{array}{c}\text { OPR } \\
(\mathrm{mmol} / \mathrm{L} . \mathrm{h})\end{array}$ & OPR/OCR \\
\hline \multirow{4}{*}{0.1} & 21 & 0.18 & 6 & 46 & 40 & 0.87 \\
& 60 & 0.61 & 10 & 88 & 78 & 0.89 \\
& 80 & 0.89 & 6 & 87 & 81 & 0.93 \\
& 100 & 1.11 & 8 & 75 & 67 & 0.89 \\
\hline \multirow{3}{*}{1} & 21 & 0.02 & 19 & 66 & 47 & 0.71 \\
& 60 & 0.10 & 50 & 232 & 182 & 0.78 \\
& 80 & 0.17 & 64 & 344 & 280 & 0.81 \\
& 100 & 0.10 & 89 & 245 & 156 & 0.64 \\
\hline
\end{tabular}

The estimated OPR/OCR ratios of all the experiments exceed their maximum theoretical value, based on the overall stoichiometry of the coupled enzyme reactions $\left(0.5 \mathrm{~mol}_{2}\right.$ produced per mol $\mathrm{O}_{2}$ consumed). Since this is not possible, it likely means that the OTRs were in fact underestimated and that the actual $\mathrm{k}_{\mathrm{L}}$ a during these experiments must have been higher than that measured in distilled water. For instance, if it is assumed that catalase operates such that the OPR is always at its theoretical maximum, average $\mathrm{k}_{\mathrm{L}}$ a values as high as 394 and $163 \mathrm{~h}^{-1}$ for GOx concentrations of 0.1 and $1 \mathrm{~g} / \mathrm{L}$, respectively, would be required to achieve sufficient OTRs to account for the OCRs. This also suggests that enzyme concentration may have a significant impact on $\mathrm{k}_{\mathrm{L}} \mathrm{a}$, in which case other components in the reaction media (glucose, gluconic acid, buffer) may also have an effect. The amphipathic nature of enzymes causes them to preferentially adsorb to the hydrophobic gasliquid interface of a bubble. ${ }^{81}$ This often leads to foaming in systems that are agitated and aerated, an effect which is exacerbated at higher enzyme concentrations. A surfactant (Antifoam 204) was manually added to the reactor when overflow, due to foaming, was observed to be imminent. Although the amount of surfactant added to the reactor was kept to an absolute minimum, 
antifoaming agents have been known to significantly reduce $\mathrm{k}_{\mathrm{L}}{ }^{82}$. Figure 7 compares the DO concentration profiles for both experiments using $80 \%$ oxygen as feed gas. The large degree of foaming at higher enzyme concentrations necessitated periodic dropwise addition of antifoam, which was immediately followed by a significant drop in the DO concentration. The gassing-in method was used to determine $\mathrm{k}_{\mathrm{L}}$ a values in mixtures containing buffer, GOx, catalase and antifoam to compare against that measured in distilled water, the results of which are shown in Table 3. The maximum dissolved oxygen concentrations measured during these experiments were also recorded. Since the DO probe was only calibrated in distilled water, these concentrations show that the mixture composition had an insignificant effect on the solubility of oxygen.

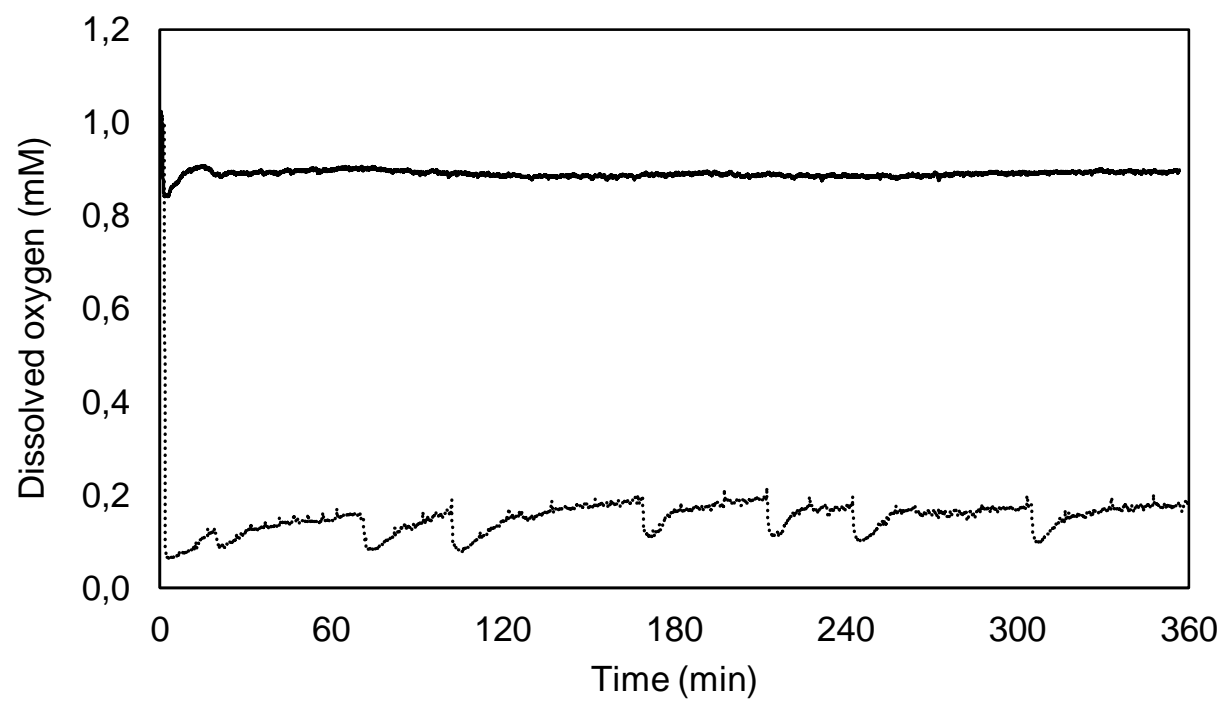

Figure 7. Dissolved oxygen concentration profiles of experiments using $80 \% \mathrm{O}_{2}$ as feed gas and GOx concentrations of $0.1 \mathrm{~g} / \mathrm{L}$ (solid line) and $1 \mathrm{~g} / \mathrm{L}$ (dotted line). Dropwise addition of antifoam to the latter to avoid reactor overflow caused significant drops in the DO concentration. 
Table 3. Mass transfer coefficients $\left(\mathrm{k}_{\mathrm{L}} \mathrm{a}\right)$ and maximum dissolved oxygen concentrations in mixtures comprised of $100 \mathrm{mM}$ potassium phosphate buffer, 0.1 g.L. $\mathrm{L}^{-1}$ glucose oxidase (GOx), 0.1 g. $\mathrm{L}^{-1}$ catalase and $0.055 \pm 0.003$ g.L $\mathrm{L}^{-1}$ antifoam.

\begin{tabular}{ccccccc}
\hline \multicolumn{5}{c}{ Mixture components } & \multirow{2}{*}{$\mathrm{k}_{\mathrm{La}}\left(\mathrm{h}^{-1}\right)$} & \multirow{2}{*}{ Max DO (mM) } \\
\hline Water & Buffer & GOx & Catalase & Antifoam & \\
\hline X & & & & & 80 & 1.21 \\
& X & & & & 159 & 1.23 \\
& X & X & & & 178 & 1.23 \\
& X & & X & & 212 & 1.21 \\
& X & X & X & & 320 & 1.21 \\
& X & X & X & X & 126 & 1.21 \\
\hline
\end{tabular}

The $\mathrm{k}_{\mathrm{L}} \mathrm{a}$ in $100 \mathrm{mM}$ potassium phosphate buffer was found to be nearly double that of distilled water. This resulted from the size of the bubbles, which were observed to be smaller due to the increased surface tension of the buffer. Addition of a low concentration $\left(0.1\right.$ g. $\left.\mathrm{L}^{-1}\right)$ of GOx to the buffer further increased the $\mathrm{k}_{\mathrm{L}}$ a by $12 \%$, while the same concentration of catalase added to the buffer raised the $\mathrm{k}_{\mathrm{L}}$ a by $33 \%$. This shows that the effect of enzymes on $\mathrm{k}_{\mathrm{L}}$ a may differ depending on their structure or formulation. When both enzymes were added to the buffer, each at a concentration of 0.1 g. $\mathrm{L}^{-1}$, the $\mathrm{k}_{\mathrm{L}}$ a was measured to be double that of buffer alone. This indicates that total enzyme concentration has a large, nonlinear effect on mass transfer of oxygen into the liquid. This likely stems from increased enzyme adsorption to the bubble interfaces, preventing them from coalescing to form larger bubbles. Therefore, at high enzyme concentrations, interfacial areas for gas-liquid mass transfer are expected to be higher. However, when a single drop of antifoam was added to this mixture the $\mathrm{k}_{\mathrm{L}} \mathrm{a}$ was reduced by $39 \%$ to a value even lower than that of pure buffer, due to a reduction in surface tension as well as preferential absorption of the surfactant to the gas-liquid interfaces. Unfortunately, this suggests that the gassing-in method cannot be used to test the effect of higher enzyme concentrations $\left(1-2\right.$ g. $\left.\mathrm{L}^{-1}\right)$ on $\mathrm{k}_{\mathrm{L}} \mathrm{a}$, due to excessive and 
uncontrollable foaming. Furthermore, since the method relies on measuring dissolved oxygen concentrations, the $\mathrm{k}_{\mathrm{L}}$ a can only be determined in the absence of any oxygen-dependent reactions. The catalytic action of GOx and catalase, as well as the presence of glucose and gluconic acid may also affect the $\mathrm{k}_{\mathrm{L} a}$. These results illustrate the complex nature of $\mathrm{k}_{\mathrm{L}} \mathrm{a}$ and how measuring it separately from the reaction, or estimating it based only on reactor properties (stirring speed and sparging rate), may result in inaccurate predictions of experimental results.

\section{CONCLUSIONS AND OUTLOOK}

Retrofitting existing batch stirred tank reactors to operate continuously not only in the gas phase, but the liquid phase as well, would potentially allow faster industrial implementation of gasdependent biocatalytic reactions than switching to tubular reactor configurations. Even so, we have demonstrated that dissolved oxygen concentrations remain the dominant rate-limiting factor of continuous GOx-catalyzed glucose oxidation in a CSTR. This likely also applies to other oxidases, which exhibit the same kinetic behavior. Although the highest reaction rates were achieved by increasing the enzyme concentration 10 -fold, this resulted in lower specific reaction rates, thereby making ineffective use of a costly catalyst. Thus, increasing oxygen partial pressure in the reactor is a more effective means of improving reaction performance. Nevertheless, the stability of the enzymes may be reduced when exposed to feed gases comprised of more than $60-80 \%$ oxygen. At atmospheric pressure, this limits the dissolved oxygen concentration to just $0.73 \mathrm{mM}$. Dependent on the $\mathrm{K}_{\mathrm{MO}}$ of an oxygen-dependent enzyme, this concentration may be sufficient to achieve industrially feasible reaction rates, but in many cases enzyme engineering will be required to further improve the affinity of enzymes towards dissolved oxygen. Additionally, our results suggest that mass transfer coefficients are dependent on media composition, further complicating accurate estimation in the absence of the reaction. A kinetic model of the system could potentially 
shed light on the true values of kinetic and oxygen transfer parameters during experiments, facilitating design and optimization of production processes.

\section{AUTHOR INFORMATION}

\section{Corresponding Author}

*Email: jw@kt.dtu.dk

\section{Author Contributions}

The manuscript was written through contributions of both authors. Both authors have given approval to the final version of the manuscript.

\section{Funding Sources}

This research was funded by the Technical University of Denmark and H. Lundbeck A/S.

\section{REFERENCES}

1. Ye, X.; Johnson, M. D.; Diao, T.; Yates, M. H.; Stahl, S. S., Development of Safe and Scalable Continuous-Flow Methods for Palladium-Catalyzed Aerobic Oxidation Reactions. Green Chem. 2010, 12 (8), 1180-1186.

2. $\quad$ Sterckx, H.; De Houwer, J.; Mensch, C.; Herrebout, W.; Tehrani, K. A.; Maes, B. U., Base metal-catalyzed benzylic oxidation of (aryl)(heteroaryl)methanes with molecular oxygen. Beilstein J. Org. Chem. 2016, 12, 144-53.

3. Pieber, B.; Kappe, C. O., Direct aerobic oxidation of 2-benzylpyridines in a gas-liquid continuous-flow regime using propylene carbonate as a solvent. Green Chem. 2013, 15 (2).

4. Ochen, A.; Whitten, R.; Aylott, H. E.; Ruffell, K.; Williams, G. D.; Slater, F.; Roberts, A.; Evans, P.; Steves, J. E.; Sanganee, M. J., Development of a Large-Scale Copper(I)/TEMPO-Catalyzed Aerobic Alcohol Oxidation for the Synthesis of LSD1 Inhibitor GSK2879552. Organometallics 2018, 38 (1), 176-184.

5. De Houwer, J.; Abbaspour Tehrani, K.; Maes, B. U., Synthesis of aryl(di)azinyl ketones through copper- and iron-catalyzed oxidation of the methylene group of aryl(di)azinylmethanes. Angew. Chem. Int. Ed. 2012, 51 (11), 2745-8.

6. Dong, J.; Fernandez-Fueyo, E.; Hollmann, F.; Paul, C. E.; Pesic, M.; Schmidt, S.; Wang, Y.; Younes, S.; Zhang, W., Biocatalytic Oxidation Reactions: A Chemist's Perspective. Angew. Chem. Int. Ed. 2018, 57 (30), 9238-9261.

7. Devine, P. N.; Howard, R. M.; Kumar, R.; Thompson, M. P.; Truppo, M. D.; Turner, N. J., Extending the application of biocatalysis to meet the challenges of drug development. Nat. Rev. Chem. 2018, 2 (12), 409-421.

8. Liu, J.; Wu, S.; Li, Z., Recent advances in enzymatic oxidation of alcohols. Curr. Opin. Chem. Biol. 2018, 43, 77-86. 
9. Lee, S. L.; O’Connor, T. F.; Yang, X.; Cruz, C. N.; Chatterjee, S.; Madurawe, R. D.; Moore, C. M. V.; Yu, L. X.; Woodcock, J., Modernizing Pharmaceutical Manufacturing: from Batch to Continuous Production. J. Pharm. Innov. 2015, 10, 191-199.

10. Hajba, L.; Guttman, A., Continuous-flow biochemical reactors: Biocatalysis, bioconversion, and bioanalytical applications utilizing immobilized microfluidic enzyme reactors. J. Flow Chem. 2016, 6 (1), 8-12.

11. Baumann, M.; Moody, T. S.; Smyth, M.; Wharry, S., A Perspective on Continuous Flow Chemistry in the Pharmaceutical Industry. Org. Process Res. Dev. 2020.

12. Malet-Sanz, L.; Susanne, F., Continuous flow synthesis. A pharma perspective. J. Med. Chem. 2012, 55 (9), 4062-98.

13. Gutmann, B.; Cantillo, D.; Kappe, C. O., Continuous-flow technology-a tool for the safe manufacturing of active pharmaceutical ingredients. Angew. Chem. Int. Ed. 2015, 54 (23), 6688728.

14. Lindeque, R. M.; Woodley, J. M., Reactor Selection for Effective Continuous Biocatalytic Production of Pharmaceuticals. Catalysts 2019, 9 (3), 262.

15. Chapman, M. R.; Kwan, M. H. T.; King, G.; Jolley, K. E.; Hussain, M.; Hussain, S.; Salama, I. E.; González Niño, C.; Thompson, L. A.; Bayana, M. E.; Clayton, A. D.; Nguyen, B. N.; Turner, N. J.; Kapur, N.; Blacker, A. J., Simple and Versatile Laboratory Scale CSTR for Multiphasic Continuous-Flow Chemistry and Long Residence Times. Org. Process Res. Dev. 2017, 21 (9), 1294-1301.

16. Paul, P. E. V.; Sangeetha, V.; Deepika, R. G., Emerging Trends in the Industrial Production of Chemical Products by Microorganisms. In Recent Developments in Applied Microbiology and Biochemistry, 2019; pp 107-125.

17. Chanique, A. M.; Parra, L. P., Protein Engineering for Nicotinamide Coenzyme Specificity in Oxidoreductases: Attempts and Challenges. Front. Microbiol. 2018, 9, 194.

18. Fetzner, S.; Steiner, R. A., Cofactor-independent oxidases and oxygenases. Appl. Microbiol. Biotechnol. 2010, 86 (3), 791-804.

19. Sander, R., Henry's Law Constants. In NIST Chemistry WebBook, NIST Standard Reference Database Number 69, P.J., L.; W.G., M., Eds. National Institute of Standards and Technology: Gaithersburg MD, 2018.

20. Tøftgaard Pedersen, A.; de Carvalho, T. M.; Sutherland, E.; Rehn, G.; Ashe, R.; Woodley, J. M., Characterization of a Continuous Agitated Cell Reactor for Oxygen Dependent Biocatalysis. Biotechnol. Bioeng. 2017, 114, 1222-1230.

21. Bolivar, J. M.; Mannsberger, A.; Thomsen, M. S.; Tekautz, G.; Nidetzky, B., Process intensification for $\mathrm{O} 2$-dependent enzymatic transformations in continuous single-phase pressurized flow. Biotechnol. Bioeng. 2019, 116 (3), 503-514.

22. Nicholls, P., Classical catalase: ancient and modern. Arch. Biochem. Biophys. 2012, 525 (2), 95-101.

23. Chapman, M. R.; Cosgrove, S. C.; Turner, N. J.; Kapur, N.; Blacker, A. J., Highly Productive Oxidative Biocatalysis in Continuous Flow by Enhancing the Aqueous Equilibrium Solubility of Oxygen. Angew. Chem. Int. Ed. 2018, 57 (33), 10535-10539.

24. Hernandez, K.; Berenguer-Murcia, A.; Rodrigues, R. C.; Fernandez-Lafuente, R., Hydrogen Peroxide in Biocatalysis. A Dangerous Liaison. Curr. Org. Chem. 2012, 16 (22), 2652-2672. 
25. Garcia-Galan, C.; Berenguer-Murcia, Á.; Fernandez-Lafuente, R.; Rodrigues, R. C., Potential of Different Enzyme Immobilization Strategies to Improve Enzyme Performance. $A d v$. Synth. Catal. 2011, 353 (16), 2885-2904.

26. Greenfield, P. F.; Kittrell, J. R.; Laurence, R. L., Inactivation of Immobilized Glucose Oxidase by Hydrogen Peroxide. Anal. Biochem. 1975, 65, 109-124.

27. Bao, J.; Furumoto, K.; Yoshimoto, M.; Fukunaga, K.; Nakao, K., Competitive inhibition by hydrogen peroxide produced in glucose oxidation catalyzed by glucose oxidase. Biochem. Eng. J. 2003, 13, 69-72.

28. Yoshimoto, M.; Takaki, N.; Yamasaki, M., Catalase-conjugated liposomes encapsulating glucose oxidase for controlled oxidation of glucose with decomposition of hydrogen peroxide produced. Colloids Surf. B 2010, 79 (2), 403-8.

29. Milton, R. D.; Giroud, F.; Thumser, A. E.; Minteer, S. D.; Slade, R. C., Hydrogen peroxide produced by glucose oxidase affects the performance of laccase cathodes in glucose/oxygen fuel cells: FAD-dependent glucose dehydrogenase as a replacement. Phys. Chem. Chem. Phys. 2013, 15 (44), 19371-9.

30. Milton, R. D.; Giroud, F.; Thumser, A. E.; Minteer, S. D.; Slade, R. C., Bilirubin oxidase bioelectrocatalytic cathodes: the impact of hydrogen peroxide. Chem. Commun. 2014, 50 (1), 94-6.

31. Nidetzky, B., Stability and stabilization of d-amino acid oxidase from the yeast Trigonopsis variabilis. Biochem. Soc. Trans. 2007, 35, 1588-1592.

32. Ju, S. S.; Lin, L. L.; Chien, H. R.; Hsu, W. H., Substitution of the critical methionine residues in Trigonopsis variabilis D-amino acid oxidase with leucine enhances its resistance to hydrogen peroxide. FEMS Microbiol. Lett. 2000, 186, 215-219.

33. Slavica, A.; Dib, I.; Nidetzky, B., Single-site oxidation, cysteine 108 to cysteine sulfinic acid, in D-amino acid oxidase from Trigonopsis variabilis and its structural and functional consequences. Appl. Environ. Microbiol. 2005, 71 (12), 8061-8.

34. Trost, E. M.; Fischer, L., Minimization of by-product formation during d-amino acid oxidase catalyzed racemate resolution of d/1-amino acids. J. Mol. Catal. B: Enzym. 2002, 19, 189-195.

35. Das, S.; Glenn, J. H. t.; Subramanian, M., Enantioselective oxidation of 2-hydroxy carboxylic acids by glycolate oxidase and catalase coexpressed in methylotrophic Pichia pastoris. Biotechnol. Prog. 2010, 26 (3), 607-15.

36. Vasudevan, P. T.; Weiland, R. H., Deactivation of Catalase by Hydrogen Peroxide Biotechnol. Bioeng. 1990, 36, 783-789.

37. Miyaji, A.; Suzuki, M.; Baba, T.; Kamachi, T.; Okura, I., Hydrogen peroxide as an effecter on the inactivation of particulate methane monooxygenase under aerobic conditions. $J$. Mol. Catal. B: Enzym. 2009, 57 (1-4), 211-215.

38. Sukyai, P.; Rezic, T.; Lorenz, C.; Mueangtoom, K.; Lorenz, W.; Haltrich, D.; Ludwig, R., Comparing soluble and co-immobilized catalysts for 2-ketoaldose production by pyranose 2oxidase and auxiliary enzymes. J. Biotechnol. 2008, 135 (3), 281-90.

39. Nordkvist, M.; Nielsen, P. M.; Villadsen, J., Oxidation of lactose to lactobionic acid by a Microdochium nivale carbohydrate oxidase: kinetics and operational stability. Biotechnol. Bioeng. 2007, 97 (4), 694-707.

40. Barlow, J. N.; Zhang, Z.; John, P.; Baldwin, J. E.; Schofield, C. J., Inactivation of 1Aminocyclopropane-1-carboxylate Oxidase Involves Oxidative Modifications. Biochemistry 1997, 36, 3563-3569. 
41. Chávez, G.; Hatti-Kaul, R.; Sheldon, R. A.; Mamo, G., Baeyer-Villiger oxidation with peracid generated in situ by CaLB-CLEA catalyzed perhydrolysis. J. Mol. Catal. B: Enzym. 2013, 89, 67-72.

42. Damm, M.; Gutmann, B.; Kappe, C. O., Continuous-Flow Synthesis of Adipic Acid from Cyclohexene Using Hydrogen Peroxide in High-Temperature Explosive Regimes. ChemSusChem 2013, 6 (6), 978-982.

43. Wu, S. H.; Chi, J. H.; Huang, C. C.; Lin, N. K.; Peng, J. J.; Shu, C. M., Thermal hazard analyses and incompatible reaction evaluation of hydrogen peroxide by DSC. J. Therm. Anal. Calorim. 2010, 102, 563-568.

44. Chi, J.-H.; Wu, S.-H.; Charpentier, J.-C.; I, Y.-P.; Shu, C.-M., Thermal hazard accident investigation of hydrogen peroxide mixing with propanone employing calorimetric approaches. J. Loss Prevent. Proc. 2012, 25 (1), 142-147.

45. Zang, N.; Qian, X., Influence of Organic Acid on Thermal Hazard of Hydrogen Peroxide. Procedia Eng. 2012, 45, 526-532.

46. Wu, S.-H.; Chou, H.-C.; Pan, R.-N.; Huang, Y.-H.; Horng, J.-J.; Chi, J.-H.; Shu, C.M., Thermal hazard analyses of organic peroxides and inorganic peroxides by calorimetric approaches. J. Therm. Anal. Calorim. 2011, 109 (1), 355-364.

47. Wu, D.; Qian, X., Experimental study on the thermal runaway of hydrogen peroxide with in-/organic impurities by a batch reactor. J. Loss Prevent. Proc. 2018, 51, 200-207.

48. Sheldon, R. A., Recent advances in green catalytic oxidations of alcohols in aqueous media. Catal. Today 2015, 247, 4-13.

49. Wijma, H. J.; Floor, R. J.; Janssen, D. B., Structure- and sequence-analysis inspired engineering of proteins for enhanced thermostability. Curr. Opin. Struct. Biol. 2013, 23 (4), 58894.

50. Singh, R. K.; Tiwari, M. K.; Singh, R.; Lee, J. K., From Protein Engineering to Immobilization: Promising Strategies for the Upgrade of Industrial Enzymes. Int. J. Mol. Sci. 2013, 14, 1232-1277.

51. Damborsky, J.; Brezovsky, J., Computational tools for designing and engineering enzymes. Curr. Opin. Chem. Biol. 2014, 19, 8-16.

52. Doukyu, N.; Ogino, H., Organic solvent-tolerant enzymes. Biochem. Eng. J. 2010, 48 (3), 270-282.

53. Woodley, J. M., Protein engineering of enzymes for process applications. Curr. Opin. Chem. Biol. 2013, 17 (2), 310-6.

54. Stepankova, V.; Bidmanova, S.; Koudelakova, T.; Prokop, Z.; Chaloupkova, R.; Damborsky, J., Strategies for Stabilization of Enzymes in Organic Solvents. ACS Catal. 2013, 3 (12), 2823-2836.

55. Wu, G.; Constantinou, A.; Cao, E.; Kuhn, S.; Morad, M.; Sankar, M.; Bethell, D.; Hutchings, G. J.; Gavriilidis, A., Continuous Heterogeneously Catalyzed Oxidation of Benzyl Alcohol Using a Tube-in-Tube Membrane Microreactor. Ind. Eng. Chem. Res. 2015, 54 (16), 4183-4189.

56. He, Z.; Jamison, T. F., Continuous-flow synthesis of functionalized phenols by aerobic oxidation of Grignard reagents. Angew. Chem. Int. Ed. 2014, 53 (13), 3353-7.

57. Stocks, S. M., Industrial enzyme production for the food and beverage industries: process scale up and scale down. In Microbial Production of Food Ingredients, Enzymes and Nutraceuticals, 2013; pp 144-172. 
58. Krischan, J.; Makaruk, A.; Harasek, M., Design and scale-up of an oxidative scrubbing process for the selective removal of hydrogen sulfide from biogas. J. Hazard. Mater. 2012, 215216, 49-56.

59. Wang, X.; Ding, J.; Guo, W.-Q.; Ren, N.-Q., Scale-up and optimization of biohydrogen production reactor from laboratory-scale to industrial-scale on the basis of computational fluid dynamics simulation. Int. J. Hydrog. Energy 2010, 35 (20), 10960-10966.

60. Bashiri, H.; Bertrand, F.; Chaouki, J., Development of a multiscale model for the design and scale-up of gas/liquid stirred tank reactors. Chem. Eng. J. 2016, 297, 277-294.

61. Hortsch, R.; Weuster-Botz, D., Milliliter-Scale Stirred Tank Reactors for the Cultivation of Microorganisms. 2010; pp 61-82.

62. Kapic, A.; Heindel, T. J., Correlating Gas-Liquid Mass Transfer in a Stirred-Tank Reactor. Chem. Eng. Res. Des. 2006, 84 (A3), 239-245.

63. Ferreira, A.; Ferreira, C.; Teixeira, J. A.; Rocha, F., Temperature and solid properties effects on gas-liquid mass transfer. Chem. Eng. J. 2010, 162 (2), 743-752.

64. Paul, E. L., Handbook of Industrial Mixing: Science and Practice. John Wiley \& Sons, Inc.: Hoboken, New Jersey, 2003.

65. Ringborg, R. H.; Tøftgaard Pedersen, A.; Woodley, J. M., Automated Determination of Oxygen-Dependent Enzyme Kinetics in a Tube-in-Tube Flow Reactor. ChemCatChem 2017, 9 , 3285-3288.

66. Pedersen, A. T.; de Carvalho, T. M.; Sutherland, E.; Rehn, G.; Ashe, R.; Woodley, J. M., Characterization of a Continuous Agitated Cell Reactor for Oxygen Dependent Biocatalysis. Biotechnol. Bioeng. 2017, 114, 1222-1230.

67. Aka, E. C.; Wimmer, E.; Barré, E.; Cortés-Borda, D.; Ekou, T.; Ekou, L.; RodriguezZubiri, M.; Felpin, F.-X., Comparing Gas-Liquid Segmented and Tube-in-Tube Setups for the Aerobic Dimerization of Desmethoxycarpacine with an Automated Flow Platform. Org. Process Res. Dev. 2020.

68. Schomburg, I.; Chang, A.; Ebeling, C.; Gremse, M.; Heldt, C.; Huhn, G.; Schomburg, D., BRENDA, the enzyme database: updates and major new developments. Nucleic Acids Res. 2004, 32, D431-3.

69. Baldwin, C. V. F.; Woodley, J. M., On Oxygen Limitation in a Whole Cell Biocatalytic Baeyer-Villiger Oxidation Process. Biotech. Bioeng. 2006, 95 (3), 362-369.

70. Bhagia, S.; Dhir, R.; Kumar, R.; Wyman, C. E., Deactivation of Cellulase at the AirLiquid Interface Is the Main Cause of Incomplete Cellulose Conversion at Low Enzyme Loadings. Sci. Rep. 2018, 8 (1), 1350.

71. Lou, H.; Zeng, M.; Hu, Q.; Cai, C.; Lin, X.; Qiu, X.; Yang, D.; Pang, Y., Nonionic surfactants enhanced enzymatic hydrolysis of cellulose by reducing cellulase deactivation caused by shear force and air-liquid interface. Bioresour. Technol. 2018, 249, 1-8.

72. Van Hecke, W.; Haltrich, D.; Frahm, B.; Brod, H.; Dewulf, J.; Van Langenhove, H.; Ludwig, R., A biocatalytic cascade reaction sensitive to the gas-liquid interface: Modeling and upscaling in a dynamic membrane aeration reactor. J. Mol. Catal. B: Enzym. 2011, 68 (2), 154161.

73. Hu, W.; Zhou, L.; Xu, Z.; Zhang, Y.; Liao, X., Enzyme inactivation in food processing using high pressure carbon dioxide technology. Crit. Rev. Food Sci. Nutr. 2013, 53 (2), 145-61.

74. Yoshimoto, M.; Yamashita, T.; Yamashiro, T., Stability and reactivity of liposomeencapsulated formate dehydrogenase and cofactor system in carbon dioxide gas-liquid flow. Biotechnol. Prog. 2010, 26 (4), 1047-53. 
75. Plumere, N.; Rudiger, O.; Oughli, A. A.; Williams, R.; Vivekananthan, J.; Poller, S.; Schuhmann, W.; Lubitz, W., A redox hydrogel protects hydrogenase from high-potential deactivation and oxygen damage. Nat. Chem. 2014, 6 (9), 822-7.

76. Darensbourg, M. Y.; Weigand, W., Sulfoxygenation of Active Site Models of [NiFe] and [FeFe] Hydrogenases - A Commentary on Possible Chemical Models of Hydrogenase Enzyme Oxygen Sensitivity. Eur. J. Inorg. Chem. 2011, 2011 (7), 994-1004.

77. Karande, R.; Schmid, A.; Buehler, K., Enzyme catalysis in an aqueous/organic segment flow microreactor: ways to stabilize enzyme activity. Langmuir 2010, 26 (11), 9152-9.

78. Talbert, J. N.; Goddard, J. M., Enzymes on material surfaces. Colloids Surf. B 2012, 93, 8-19.

79. Pinelli, D.; Liu, Z.; Magelli, F., Analysis of kLa Measurement Methods in Stirred Vessels: The Role of Experimental Techniques and Fluid Dynamic Models. Int. J. Chem. React. Eng. 2010, 8 (1).

80. Tøftgaard Pedersen, A.; Birmingham, W. R.; Rehn, G.; Charnock, S. J.; Turner, N. J.; Woodley, J. M., Process Requirements of Galactose Oxidase Catalyzed Oxidation of Alcohols. Org. Process Res. Dev. 2015, 19 (11), 1580-1589.

81. Khalesi, M.; Venken, T.; Deckers, S.; Winterburn, J.; Shokribousjein, Z.; Gebruers, K.; Verachtert, H.; Delcour, J.; Martin, P.; Derdelinckx, G., A novel method for hydrophobin extraction using CO2 foam fractionation system. Ind. Crop. Prod. 2013, 43, 372-377.

82. Routledge, S.; Poyner, D.; Bill, R., Antifoams: the overlooked additive? Pharm.

Bioprocess. 2014, 2 (2), 103-106. 